\title{
Peran Pemerintah Daerah dalam Pengembangan Desa Wisata Paksebali di Kabupaten Klungkung
}

\author{
Putu Sukma Wahyuni Dewi' ${ }^{1}$, Luh Nyoman Tri Lilasari², I Gede Gian Saputra ${ }^{3}$ \\ 1,2,3 Program Studi Manajemen Kepariwisataan, Politeknik Pariwisata Bali \\ Jl. Dharmawangsa Kampial, Nusa Dua Bali, Telp. (0361) 773537
}

E-mail: ${ }^{1}$ sukmawahyudewiii@yahoo.com, 2trililasari_ila@ppb.ac.id, 39ian.stpnb@gmail.com

\begin{tabular}{l|l|l} 
Received: Mei, 2021 & Accepted: Mei, 2021 & Published: June, 2021
\end{tabular}

\begin{abstract}
This research aims to study the role of local government in the development of Paksebali Tourism Village, from the perspective of local community, tourism village team, and the Klungkung District Government. Data were collected by observation, survey, interviews, documentation and analyzed using qualitative descriptive analysis techniques. The results showed that local people and tourism village team strongly agreed with the government's Paksebali Tourism Village development programe. As a facilitator the government facilitated tourism programs, projects and activities, provided innovations, involved the community to participate, socialization and financial assistance. As evaluators, the government assessed the programs, monitored tourism development and made satisfaction surveys, as implementers, the governmentleaded and coordinated programs, projects and activities for the development of tourist villages, established good relationships with relevant agencies and regulated tourism development such as making environmental sustainability, health and safety standards. Of the four roles, the role of the government as facilitator obtained the highest score of 4.35, and as the evaluator obtained the lowest score of 4.21. To maximize the role of the government, this study recommended the government conduct monitoring and evaluation on the development of Paksebali Tourism Village at least once a month by involving the community and leaders.
\end{abstract}

Keywords: government, local government, tourism village

\begin{abstract}
Abstrak
Penelitian ini bertujuan untuk mengetahui peran pemerintah daerah dalam pengembangan Desa Wisata Paksebali. Dari perspektif yaitu pendapat masyarakat lokal dan pengelola desa wisata, serta dari Pemerintah Daerah Kabupaten Klungkung. Teknik pengumpulan data dilakukan dengan observasi, survei, wawancara, dan dokumentasi. Data yang diperoleh dianalisis dengan teknik analisis deskriptif kualitatif. Hasil penelitian menunjukan bahwa masyarakat lokal dan pengelola desa wisata sangat setuju dengan program pemerintah dalam pengembangan Desa Wisata Paksebali. Peran pemerintah sebagai fasilitator sudah memfasilitasi program, proyek dan kegiatan pariwisata, memberikan inovasi, mengikutsertakan masyarakat untuk berpartisipasi, adanya sosialisasi dan bantuan dana. Sebagai evaluator, pemerintah menilai program-program yang sudah terlaksana, memantau
\end{abstract}


Putu Sukma Wahyuni Dewi, Luh Nyoman Tri Lilasari, I Gede Gian Saputra

pembangunan pariwisata dan membuat survei kepuasan, sebagai implementer, pemerintah memimpin dan mengkoordinasikan program, proyek dan kegiatan untuk pengembangan desa wisata, menjalin hubungan yang baik dengan instansi terkait dan mengatur pengembangan pariwisata seperti membuat standar kelestarian lingkungan, kesehatan dan keselamatan. Dari keempat peran tersebut, peran pemerintah sebagai fasilitator mendapatkan nilai tertinggi yaitu 4,35, sebagai evaluator mendapatkan nilai terendah yaitu 4,21. Untuk memaksimalkan peran pemerintah, penelitian ini merekomendasikan pemerintah untuk melakukan kegiatan pemantauan dan evaluasi terhadap pengembangan Desa Wisata Paksebali minimal sebulan sekali dengan melibatkan masyarakat dan pengelola.

Kata Kunci : pemerintah, pemerintah daerah. Desa Wisata

\section{PENDAHULUAN}

Pembangunan desa wisata merupakan realisasi dari pelaksanaan UndangUndang Nomor 23 Tahun 2015 Tentang Otonomi Daerah. Pasal 12 ayat 3 menjelaskan bahwa pariwisata adalah salah satu urusan pemerintahan pilihan. Sehingga perencana pengembangan daerah wisata dapat dimulai dengan mengenali potensi wilayah yang akan dijadikan sebagai lokasi pengembangan kepariwisataan. Dalam pelaksanaannya, yang diamanatkan dalam Undang-Undang tersebut belum sepenuhnya dapat dinikmati oleh masyarakat luas tetapi hanya dinikmati oleh sekelompok orang saja. Pengembangan desa wisata merupakan salah satu alternatif yang dipandang sangat strategis untuk menjawab sejumlah isu global dan nasional terkait dengan pariwisata seperti konservasi lingkungan, pariwisata berkelanjutan, pariwisata berbasismasyarakat, komunitas, serta budaya lokal tersebut(IHGMA, 2018). Hal ini juga sesuai dengan peraturan mengenai otonomi daerah memberikan kebebasan pada pemerintah daerah untuk mengelola pariwisatanya. Hal ini tertuang dalam Undang-Undang Nomor 23 tahun 2015 tentangpemerintahan daerah.

Pemerintah Provinsi Bali melahirkan kebijakan yang mendukung percepatan pembangunan desa wisata. Dinas Pariwisata Provinsi Bali menerbitkan Surat Edaran Kadisparda Provinsi Bali Nomor 556/317/I/DISPAR tentang Pengembangan 100 Desa Wisata Tahun 2014-2018 di Bali. Berdasarkan data dari Dinas Pariwisata Provinsi Bali pada tahun 2019 tercatat terdapat 165 desa wisata yang sudah memiliki SK (Surat Keputusan) dari Pemkab masing-masing. Kepala BPS Bali Adi Nugroho mengatakan data ini didapat dengan melakukan pendataan potensi desa (Podes) yang biasanya dilaksanakan tiga kali selama sepuluh tahun. Pendataan potensi desa sebelumnya dilakukan pada 2014, dan saat ini kembali dilakukan sejak Mei 2018 (bisnis.com).

Basis konsep pengembangan desa wisata berdasarkan hasil analisis Kemenparekraf tahun2014 yang dikutip dalam biizaa.com menyatakan bahwa ada 3 (tiga) konsep pengembangan desawisata yaitu Nature (35\%), Culture (60\%)dan Manmade (5\%). Sama halnya dengan 142 desa wisata yang sudah tercatatmemiliki SK, setiap desawisata yang ada di Provinsi Bali memiliki keunikandan pesonanya sendiri.

Kabupaten Klungkung telah mengem-bangkan pariwisata sebagai salah satu sektor penyumbang pendapatan daerah dan juga merupakan salah satu kabupaten yang ikut mengembangkan pariwisata berbasis desa wisata. Sesuai dengan 
Putu Sukma Wahyuni Dewi, Luh Nyoman Tri Lilasari, I Gede Gian Saputra

Peraturan Bupati Klungkung Nomor 2 Tahun 2017 tentang penetapan desa wisata menyatakan bahwa desa wisata adalah wilayah pelestarian alam lingkungan ekosistem serta simpul budaya tradisional masyarakat dengan tidakmenghambat perkembangan warganya untuk meningkatkan kesejahteraan hidupnya melalui usaha kepariwisataan. Jumlah desa wisata berdasarkan Surat Keputusan Bupati Klungkung tahun 2017 menetapkan terdapat 18 desa wisata.

Tabel 1.

Desa Wisata di Kabupaten Klungkung

\begin{tabular}{cll}
\hline No & \multicolumn{1}{c}{ Nama Desa Wisata } & \multicolumn{1}{c}{ Kecamatan } \\
\hline 1 & Desa Wisata Tihingan & Banjarangkan \\
2 & Desa Wisata Timuhun & Banjarangkan \\
3 & Desa Wisata Bakas & Banjarangkan \\
4 & Desa Wisata Kamasan & Klungkung \\
5 & Desa Wisata Tegak & Klungkung \\
6 & Desa Wisata Gelgel & Klungkung \\
7 & Desa Wisata Besan & Dawan \\
8 & Desa Wisata Pesinggahan & Dawan \\
9 & Desa Wisata Paksebali & Dawan \\
10 & Desa Wisata Jungutbatu & Nusa Penida \\
11 & Desa Wisata Lembongan & Nusa Penida \\
12 & Desa Wisata Ped & Nusa Penida \\
13 & Desa Wisata Batu Kandik & Nusa Penida \\
14 & Desa Wisata Tanglad & Nusa Penida \\
15 & Desa Wisata Batu Nunggul & Nusa Penida \\
16 & Desa Wisata Kelumpu & Nusa Penida \\
17 & Desa Wisata Pejukutan & Nusa Penida \\
18 & Desa Wisata Suana & Nusa Penida \\
\hline
\end{tabular}

Sumber: Perbup Klungkung No.2 Tahun 2017

Desa Wisata Paksebali merupakan salah satu dari 18 desa wisata dalam pengembangannya mengalami beberapa kendala, yaitu (1) masih ada banyak potensi atraksi yang memiliki daya tarik belum dikelola dengan baik, (2) kurangnya promosi sehingga kurang dikenal wisatawan, (3) kurangnya membuat terobosanterobosan dan koordinasi dengan lembaga terkait, (4) jumlah kunjungan wisatawan asing maupun domestik ke Desa Wisata Paksebali belum sesuai yang diharapkan, (5) manajemen operasional desa masih belum optimal karena kualitas sumber daya manusia yang belum kompeten, (6) Produk wisata yang telah direncanakan belum dipasarkan dan beberapa masalah lainnya (Pantiyasa, 2019).

Desa Wisata Paksebali telah mengem- bangkan pariwisata sebagai salah satu sektor penyumbang pendapatan desa. Desa Wisata Paksebali memiliki potensi wisata yang sangat menarik mulai dari wisata alam, wisata budaya dan wisata buatan. Desa Wisata Paksebali memiliki unique selling point yang menjadi daya tarik wisata tetapi, jumlah kunjungan wisatawan yang datang ke Desa Wisata Paksebali belum sesuai dengan yang diharapkan. 
Tabel 2.

Kunjungan Wisatawan ke Desa Wisata Paksebali

\begin{tabular}{ccccc}
\hline No & Tahun & Domestik & Manca & Total \\
\hline 1 & 2019 & 20.679 & 1.784 & 22.463 \\
2 & 2020 & 2.384 & 260 & 2.644 \\
& (Jan-Feb) & & & \\
\hline
\end{tabular}

Sumber : Dispar Kabupaten Klungkung, 2020

Jumlah kunjungan wisatawan ke Desa Wisata Paksebali pada tahun 2019 hanya mencapai 22.463 wisatawan. Berdasarkan hasil wawancara yang dilakukan dengan I Putu Ariadi selaku Kepala Desa Wisata Paksebali menyatakan bahwa jumlah kunjungan tersebut tidak sesuai dengan harapan karena dari pihak pengelola desa wisata menargetkan jumlah kunjungan wisatawan ke Desa Wisata Paksebali mencapai 50.000 wisatawan pertahunnya. Pada tahun 2020 jumlah kunjungan wisatawan ke Desa Wisata Paksebali mengalami penurunan drastis karena adanya pandemic Covid-19. Hal ini karena adanya penutupan sementara daya tarik wisata untuk mencegah penyebaran Covid-19. Perkembangan pariwisata yang terjadi di Desa Wisata Paksebali tentunya tidak lepas dari peran penting dari pihak stakeholder seperti antara pihak pengelola, masyarakat Desa Wisata Paksebali itu sendiri, serta pemerintah yang berfungsi sebagai fasilitator, perencana, evaluator dan implementer yang dimana akan membantu dalam mewujudkan pengembangan pariwisata yang berkesinambungan.

Pada prinsipnya pengembangan pariwisata yang baik harus saling koordinasi dan sinkronisasi antar stakeholder yang ada serta keterlibatan partisipasi aktif yang saling terpadu dan saling menguatkan antar pihak pemerintah dengan pihak masyarakat. Oleh karena itu melihat lebih dalam seberapa pentingnya peran pemerintah yang dalam hal ini melibatkan Dinas Pariwisata dan Dinas Kebudayaan serta pendapat masyarakat lokal dan pengelola desa wisata serta pada saat ini belum adanya kajian yang dilakukan terkait dengan sejauh mana peran pemerintah daerah Kabupaten Klungkung dalam pengembangan pariwisata khususnya di Desa Wisata maka penelitian tentang "peran pemerintah daerah dalam pengembangan Desa Wisata Paksebali di Kabupaten Klungkung" perlu dilakukan untuk dijadikan bahan evaluasi baik bagi pemerintah daerah atau bagi pengelola di Desa Wisata Paksebali agar bisa menjadi desa wisata yang berkualitas dan berkelanjutan.

\section{LANDASAN TEORI}

Istilah pariwisata yaitu suatu perubahan tempat tinggal sementara seseorang diluar tempat tinggalnya karena suatu alasan dan bukan untuk melakukan kegiatan yang menghasilkan upah (Suwantoro, 2004). Dengan demikian dapat dikatakan bahwa perjalanan yang dilakukan oleh seseorang atau lebih dengan tujuan antara lain untuk mendapatkan kenikmatan dan memenuhi hasrat ingin mengetahui sesuatu. Dapat juga karena kepentingan yang berhubungan dengan kegiatan olah raga untuk kesehatan, konvensi, keagamaan, dan keperluan usaha lainnya. Potensi wisata adalah semua obyek (alam, budaya, buatan) yang memerlukan banyak penanganan agar dapat memberikan nilai daya tarik bagi wisatawan (Janianto Damanik dan Helmut F.Weber, 2006). 
Menurut Undang-Undang No. 10 Tahun 2009 Tentang Kepariwisataan Bab I Pasal 1 ; dinyatakan bahwa wisata adalah kegiatan perjalanan yang dilakukan oleh seseorang atau sekelompok orang dengan mengunjungi tempat tertentu untuk tujuan rekreasi, pengembangan pribadi atau mempelajari keunikan daya tarik wisata yang kunjungi dalam jangka waktu sementara.

World Tourism Organization (2017) mendefinisikan pariwisata sebagai suatu aktivitas perjalanan ke suatu tempat dan tinggal di luar lingkungan mereka seharihari tidak lebih dari setahun dan bertujuan untuk istirahat atau bersenang-senang, bisnis, dan tujuan lainnya yang tidak terkait dengan aktivitasnya sehari-hari selama mereka berada di daerah tujuan wisata.

Menurut Yoeti (2002) bahwa keberhasilan suatu tempat wisata hingga tercapainnya kawasan wisata sangat tergantung pada 3A yaitu atraksi (Attraction), mudah dicapai (Accessibilty), dan fasilitas (Amenities).

Menurut Cooper dkk (1993) bahwa terdapat empat komponen yang harus dimiliki oleh sebuah destinasi wisata antara lain:(1). Atraksi atau Attraction, seperti alam yang menarik, kebudayaan daerah yang menawan dan seni pertunjukkan, (2). Fasilitas atau Amenities, seperti tersedianya akomodasi, rumah makan, dan agen perjalanan, (3). Aksesibilitas atau Accessibility, seperti transportasi lokal dan tersedianya pelayanan penyewaan mobil, serta tersedianya terminal maupun bandara untuk mempermudah akses menuju lokasi wisata. (4) Ancillary service yaitu organisasi kepariwisataan yang dibutuhkan untuk pelayanan wisata seperti destination marketing management organization, conventional and visitor bureau.

Menurut Zakaria dan Suprihardjo (2014) "Desa wisata adalah suatu wilayah pedesaan yang menawarkan keaslian baik darisegi sosial budaya, adat istiadat, keseharian, arsitektur tradisional, struktur tata ruang desa yang disajikan dalam suatu bentuk integrasi komponen pariwisata antara lain seperti atraksi, akomodasi dan fasilitas pendukung." Selain itu desa wisata merupakan suatu bentuk integrasi antara atraksi, akomodasi, dan fasilitas pendukung yang disajikan dalam suatu struktur kehidupan masyarakat yang menyatu dengan tata cara dan tradisi yang berlaku (Nuryani dalam Badan Pengembangan Sumber Daya Kementerian Pariwisata dan Ekonomi Kreatif, 2011).

Sementara menurut Inskeep (dalam Badan Pengembangan Sumber Daya Kementerian Pariwisata dan Ekonomi Kreatif, 2011), desa wisata atau village tourism adalah suatu fasilitas wisata yang memungkinkan pengunjung tinggal di dalam atau di dekat desa, umumnya merupakan desa tradisional. Kegiatan wisata yang dilakukan adalah belajar tentang kehidupan pedesaan, tata cara lokal, dan berpatisipasi dalam aktivitas penduduk.

Pola pengembangan Desa Wisata diharapkan memuat prinsipprinsip sebagai berikut (Departemen Kebudayaan dan Pariwisata, 2011):

1) Tidak bertentangan dengan adat istiadat atau budaya masyarakat. Suatu desa yang tata cara ada istiadatnya masih mendominasi pola kehidupan masyarakat, dalam pengem-bangannya sebagai atraksi wisata harus disesuaikan dengantata cara yang berlaku di desanya.

2) Pengembangan fisik untuk meningkatkan kualitas lingkungan desa dengan pengembangan pariwisata di suatu desa pada hakikatnya tidak merubah yang sudah ada di desa tersebut, tetapi lebih kepada upaya merubah yang ada di desa dan kemudian mengemasnya sedemikian rupa sehingga menarik untuk dijadikan 
atraksi wisata. Pengembangan fisik yang dilakukan dalam rangka pengembangan desa seperti penambahan sarana jalan setapak, menyediakan toilet, menyediakan sarana dan prasarana air bersih dan sanitasi lebih ditunjukan untuk meningkatkan kualitas lingkungan yang ada sehingga desa tersebut dapat dikunjungi dan dinikmati wisatawan.

3) Memperhatikan unsur kelokalan dan keaslian arsitektur bangunan, pola landscape serta material yang digunakan dalam pengembangan haruslah menonjolkan ciri khas suatu desa, untuk mencerminkan kelokalan dan keaslian wilayah setempat.

4) Memperdayakan masyarakat desa wisata. Unsur penting dalam pengembangan desa wisata adalah keterlibatan masyarakat desa dalam setiap aspek wisata yang ada di desa tersebut. Pengembangandesa wisata sebagai dari konsep "Pariwisata Inti Rakyat" mengandung arti bahwa masyarakat desa memperoleh manfaat sebesar-besarnya dalam pengembangan pariwisata dalam bentuk pemberian jasa dan pelayanan yang hasilnya dapat meningkatkan pendapatan masyarakat diluar aktivitas mereka sehari-hari.

5) Memperhatikan daya dukung dan berwawasan lingkungan. Prinsip-prinsip pariwisata yang berkelanjutan (Sustainable Tourism) harus mendasari pengembangan desa wisata. Pengembangan yang melampui daya dukung akan menimbulkan dampak yang besar tidak hanya pada lingkungan alam tetapi juga pada kehidupan sosial budaya masyarakat yang pada akhirnya akan mengurangi daya tarik desa tersebut. Beberapa bentuk keterlibatan masyarakat tersebut adalah penyediaan fasilitas akomodasi berupa rumah-rumah penduduk (homestay), penyediaan kebutuhan konsumsi wisatawan, pemandu wisata penyediaan transportasi lokal, pertunjukan kesenian, dan lainlain.

Poerwodarminta (1995) menyatakan bahwa peran merupakan tindakan yang dilakukan seseorang atau sekelompok orang dalam suatu peristiwa. Dimana peran merupakan perangkat tingkah laku yang diharapkan, dimiliki oleh orang atau seseorang yang berkedudukan di masyarakat. Menurut Soekanto (2004), menyebutkan bahwa peran dapat dibagi menjadi 3 cakupan yaitu :

1. Peran meliputi norma-norma yang dihubungkan dengan posisi atau tempat seseorang dan masyarakat, peran dalam arti merupakan rangkaianrangkaian peraturan yang membimbing seseorang dalam kehidupan ke masyarakat.

2. Peran adalah suatu konsep tentang yang dilakukan oleh individu dalam masyarakat sebagai organisasi.

3. Peran juga dapat dikatakan sebagai individu yang penting bagi struktur organisasi sosial masyarakat.

Berdasarkan 3 cakupan tersebut, dapat disimpulkan bahwa peran pemerintah dalam hal ini mencakup 3 aspek yang dimana aspek tersebut adalah penilaian terhadap perilaku sesorang yang ada di masyarakat terkait dengan posisi dan juga kedudukannya.

Konsep-konsep yang dilakukan sesorang dalam masyarakat dengan kedudukannya, serta perilaku sesorang yang penting bagi struktur sosial masyarakat. Menurut Soekanto (2003) peranan adalah aspek dinamis kedudukan (status). Peranan merupakan aspek dinamis kedudukan (status). 
Apabila seseorang melaksanakan hak dan kewajibannya sesuai dengan kedudukannya, maka ia menjalankan suatu peranan. Peranan mencakup tiga hal yaitu :

1) Peranan meliputi norma-norma yang dihubungkan dengan posisi atau tempat seseorang dalam masyarakat. Peranan dalam arti ini merupakan rangkaian peraturan-peraturan yang membimbing seseorang dalam kehidupan masyarakat.

2) Peranan adalah suatu konsep tentang yang dapat dilakukan olehindividu dalam masyarakat dalam organisasi.

3) Peranan juga dapat dikatakan sebagai perilaku yang penting bagi struktur sosial masyarakat UNWTO dalam Pitana dan Diarta (2009) menyatakan bahwa peran pemerintah dalam menentukan kebijakan.

Menurut Rasyid (2000) peran pemerintahan adalah untuk melayani dan mengatur masyarakat, lebih menekankan upaya mendahulukan kepentingan umum, mempermudah urusan publik dan memberikan kepuasan kepada publik, sedangkan tugas mengatur lebih menekankan kekuasaan power yang melekat pada posisi jabatan birokrasi. Menurut Rasyid (2000) memaparkan bahwa enam tugas umum pemerintah antara lain menjamin keamanan negara dari segala ancaman. Secara umum peran pemerintah mencakup tiga peran pokok yang seharusnya dijalankan oleh pemerintah baik pemerintah pusat maupun pemerintah daerah $\mathrm{H}$. Nurul dalam Haryanto (1997).

1) Peran Pengaturan, peran ini dilaksanakan pemerintahan dengan membuat peraturan perundang-undangan untuk mengatur hubungan manusia dalam masyarakat. Pemerintah adalah pihak yang mampu menerapkan peraturan agar kehidupan dapat berjalan secara baik dan dinamis. Seperti halnya peran pemerintah pusat, pemerintah daerah juga mempunyai peran pengaturan terhadap masyarakat yang ada di daerahnya.

2) Peran pelayanan umum (public service), peran pelaksanaan yangdilakukan Pemerintah Pusat dan Pemerintah Daerah terletak pada kewenangan masingmasing. Kewenangan Pemerintah Pusat mencakup urusan petahanan. Keamanan Agama, Hubungan Luar Negeri, Moneter dan Peradilan.

3) Peran Pemberdayaan, peran ini untuk mendukung terselenggaranya otonomi daerah, fungsi ini menuntut pemberdayaan Pemerintah Daerah dengan kewenangan yang cukup dalam pengelolaan sumber daya daerah guna melaksanakan berbagai urusan yang di desentralisasikan. Untuk itu Pemerintah Daerah perlu meningkatkan peran serta masyarakat dan swasta dalam kegiatan pembangunan dan penyelenggaraan pemerintah. Kebijakan pemerintah, pusat dan daerah, diarahkan untuk meningkatkan aktivitas ekonomi masyarakat, yang pada jangka panjang dapat menunjung pendanaan Pemerintah Daerah.

\section{METODE PENELITIAN}

Metode yang digubakan dalam penelitian ini adalah penelitian kualitatif dan metode kuantitatif dengan menggunakan pendekatan deskriptif. Objek yang diteliti dalam penelitian ini yaitu peran pemerintah yang ditinjau dari peran pemerintah sebagai fasilitator, perencana, evaluator dan implementer yang dimana dalam hal ini ditinjau dari masyarakat lokal, pengelola desa wisata. Dinas Pariwisata dan Dinas Kebudayaan Kabupaten Klungkung. 
Putu Sukma Wahyuni Dewi, Luh Nyoman Tri Lilasari, I Gede Gian Saputra

Teknik pengumpulan data yang digunakan dalam penelitian ini adalah mobservasi, survei, wawancara, dokumentasi dan studi literatur. Teknik analisis data yang digunakan dalam penelitian ini adalah teknik analisis deskriptif kualitatif. Untuk mengetahui pendapat masyarakat dan pengelola Desa Wisata Paksebali, menggunakan pendekatan statistik deskriptif yang akan dijabarkan secara kualitatif dengan skala pengukuran yaitu skala likert.

\section{HASIL DAN PEMBAHASAN}

\subsection{Peran Pemerintah dalam Pengembangan Desa Wisata Paksebali}

Berdasarkan hasil uji statistik variabel fasilitator menunjukan bahwa seluruh indikator memiliki koefisien korelasi yang lebih besar dari 0,361. Hal tersebut menyatakan bahwa seluruh indikator dalam variabel fasilitator dinyatakan valid. Pada indikator kedua yaitu memberikan inovasi-inovasi baru dalam pengembangan Desa Wisata Paksebali memiliki nilai r-hitung tertinggi yaitu 0.870 setelah itu pada indikator adanya sosialisasi dan pembinaan masyarakat untuk pengembangan Desa Wisata Paksebali memiliki nilai r-hitung tertinggi kedua yaitu 0.868. Pada indikator memfasilitasi program, proyek atau kegiatan kepariwisataan memiliki nilai r-hitung tertinggi ketiga yaitu 0.846. Pada indikator mengikutsertakan masyarakat untuk berpartisipasi dalam pengembangan Desa Wisata Paksebali memiliki nilai r-hitung tertinggi keempat yaitu 0.798 sedangkan pada indikator memberikan bantuan dana untuk kegiatan kepariwisataan di Desa Wisata Paksebali dengan nilai r-hitung terkecil yaitu 0.775 .

Variabel perencana menunjukan bahwa seluruh indikator memiliki koefisien korelasi yang lebih besar dari 0,361. Hal tersebut menyatakan bahwa seluruh indikator dalam variabel perencana dinyatakan valid. Pada indikator memperkirakan kemungkinan adanya peluang dan potensi masalah memiliki nilai r-hitung tertinggi yaitu 0.921 hal ini karena Pemerintah Daerah Kabupaten Klungkung bekerjasama dengan pengelola desa wisata dan akademisi untuk mengidentifikasi SWOT (strength, weakness, opportunities, threats) pada Desa Wisata Paksebali. Selanjutnya pada indikator mengalokasikan anggaran untuk rencana mengembangkan desa wisata memiliki nilai $r$ - hitung tertinggi kedua yaitu 0.892. Pada indikator membuat program, proyek dan kegiatan tahunan memiliki nilai $r$-hitung tertinggi ketiga yaitu 0.882 sedangkan pada indikator merencanakan adanya master plan untuk pengembangan desa wisata memilki nilai r-hitung terendah dengan yaitu 0.788 .

Variabel evaluator menunjukan bahwa seluruh indikator memiliki koefisien korelasi yang lebih besar dari 0,361. Hal tersebut menyatakan bahwa seluruh indikator dalam variabelevaluator dinyatakan valid. Pada indikator menilai program-program yang sudah terlaksana memiliki nilai r-hitung tertinggi yaitu 0.842. Pemerintah Daerah Kabupaten Klungkung selalu melakukan penilaian terhadap program yang sudah terlaksana sebagai bahan evaluasi dan pertimbangan terhadap program-program mendatang. Pada indikator menyiapkan instrumen penilaian terhadap programprogram yang terlaksanamemiliki nilai $r$-hitung tertinggi kedua yaitu 0.832 sedangkan pada indikator terakhir yaitu memantau pembangunan pariwisata dan memperhatikan trendseperti membuat survei kepuasan pengunjung dan memonitoring memiliki nilai $r$-hitung terendah yaitu 0.773 . 
Putu Sukma Wahyuni Dewi, Luh Nyoman Tri Lilasari, I Gede Gian Saputra

Variabel implementer menunjukan bahwa seluruh indikator memiliki koefisien korelasi yang lebih besar dari 0,361. Hal tersebut menyatakan bahwa seluruh indikator dalam variabel implementer dinyatakan valid. Pada indikator menjalin hubungan yang baik dengan instansi-instansi terkait agar pengembangan desa wisata berjalandengan baik dan maksimal memiliki nilai r-hitung tertinggi yaitu 0.936. Pada indikator mengatur pengembangan pariwisata misalnya membuat standar-standar kelestarian lingkungan, kesehatan dan keselamatan memilikinilai r-hitung kedua tertinggi yaitu 0.854 sedangkan pada indikator terakhir yaitu memimpin dan mengkoordinasikan program, proyek dan kegiatan untuk pengembangan desa wisata mendapat nilai $r$-hitung terendah yaitu 0.834 .

Tabel 3. Hasil Uji Reliabilitas Variabel Peran Pemerintah dalam Pengembangan Desa Wisata Paksebali

\begin{tabular}{ccccc}
\hline No & Variabel & Cronbach's Alpa & $\begin{array}{c}\text { Rules of } \\
\text { Tumb }\end{array}$ & Keterangan \\
\hline 1 & Fasilitator & 0.888 & 0.60 & Reliabel \\
2 & Perencana & 0.892 & 0.60 & Reliabel \\
3 & Evaluator & 0.747 & 0.60 & Reliabel \\
4 & Implementer & 0.834 & 0.60 & Reliabel \\
\hline
\end{tabular}

Sumber: Hasil Penelitian, 2021

Berdasarkan pada tabel 3 dapat dilihat bahwa nilai Cronbach's Alpa dari keempat variabel tersebut, variabel perencana memiliki nilai Cronbach's Alpa tertinggi yaitu 0.892 yang berarti dimana pemerintah memiliki peran yang cukup besar dalam merencanakan pengembangan Desa Wisata Paksebali. Pada variabel fasilitator memiliki nilai Cronbach's Alpa 0.888 dimana menjadi variabel dengan nilai tertinggi kedua setelah perencana. Pemerintah Daerah Kabupaten Klungkung melalui Dinas Pariwisata Kabupaten Klungkung memfasilitasi pengembangan Desa Wisata Paksebali dengan meningkatkan kualitas sumber daya manusia dengan melakukan kegiatan seminar, sosialisasi dan focus group discussion. Pada variabel implementer memiliki nilai Cronbach's Alpa 0.834 dimana merupakan nilai tertinggi ketiga setelah perencaan dan fasilitator. Pada variabel terakhir yaitu evaluator memiliki nilai Cronbach's Alpa 0.747. Pemerintah Daerah Kabupaten Klungkung rutin melakukan program monitoring dan evaluasi untuk mengetahui kinerja pengelola desa wisata dalam pengembangan Desa Wisata Paksebali.

\subsection{Peran Pemerintah Daerah dalam Pengembangan Desa Wisata Paksebali}

Desa Wisata Paksebali dalam pengem-bangannya sebagai desa wisata lebih banyak menggunakan dana desa. Dana desa berkontribusi pada berbagai kegiatan pembangunan dan kini telah dinikmati oleh masyarakat. Di antaranya adalah jalan desa yang semakin baik, sanitasi lingkungan yang tertata, pengelolaan sampah, kualitas layanan pos kesehatan serta kualitas PAUD yang makin meningkat. Selain pengembangan desa wisata, prioritas penggunaan dana desa adalah untuk pemberdayaan masyarakat yang merupakan roket pendorong pengembangan desa. Oleh karena itu, pemerintah desa dengan bijak mengalokasikan dana untuk meningkatkan kapasitas Lembaga Masyarakat dan pemberian Bantuan Siswa Miskin. 
Dana desa ini diatur dalam Peraturan Pemerintah (PP) Nomor 60 Tahun 2014 tentang dana desa yang bersumber dari Anggaran Pendapatan Belanja Negara (APBN). Berdasarkan PP Nomor 60 Tahun2014, Dana Desa adalah dana yang bersumber dari APBN yang diperuntukan bagi desa yang di transfer melalui Anggaran Pendapatan Belanja Daerah (APBD) Kabupaten atau Kota dan digunakan untuk membiayai penyelenggaraan pemerintah, pelaksanan pembangunan, pembinaan kemasyarakatan dan pemberdayaan masyarakat.

Kualitas pelayanan dengan membuat survei pengunjung dalam pengembangan di Desa Wisata Paksebali merupakan tugas dan tanggung jawab pengelola dan masyarakat. Desa Wisata Paksebali sudah melakukan upaya-upaya untuk wisatawan bisa menilai kesan dan pesan selama berkunjung ke Desa Wisata Paksebali baik secara online melalui sosial media maupun offline melalui pengelola. Dengan adanya survei kepuasan pengunjung memberikan inspirasi baik bagi pemerintah maupun pengelola untuk memperbaiki dan meningkatkan kinerja sektor pelayanan publik. Pemerintah Daerah Kabupaten Klungkung melakukan kegiatan monitoring ke Desa Wisata Paksebali selambat- lambatnya dua bulan sekali untuk mengetahui perkembangan pariwisata danmengetahui jumlah kunjungan baik wisatawan domestic maupun mancanegara.

Pemerintah Daerah Kabupaten Klungkung mendukung segala kegiatan untuk pengembangan desa Wisata Paksebali. Untuk mencapai semua tujuan pengembangan desa wisata, pemda Klungkung terus melakukan koordinasi dengan pihak Desa Wisata Paksebali. Ada sebagaian kewenangan pemerintah daerah yang diserahkan kewenangannya kepada pemerintah desa. Desa merupakan selfcommunity yaitu komunitas yang mengatur dirinya sendiri. Dengan pemahaman bahwa Desa memiliki kewenangan untuk mengurus dan mengatur kepentingan masyarakatnya sesuai dengan kondisi dan sosial budaya setempat.

\section{KESIMPULAN}

Berdasarkan hasil penelitian yang dilakukan mengenai peran pemerintah dalam pengembangan Desa Wisata Paksebali di Kabupaten Klungkung yang telah dipaparkan, maka diperoleh kesimpulan sebagai berikut:

1. Berdasarkan hasil penyebaran kuesioner kepada masyarakat dan pengelola desa wisata serta wawancara dengan Pemerintah Daerah Kabupaten Klungkung yang dalam hal ini yaitu Dinas Pariwisata dan Dinas Kebudayaan didapatkan hasil bahwa yang pemerintah lakukan terhadap pengembangan Desa Wisata Paksebali sejalan dengan yang diharapkan oleh masyarakat. Pemerintah Daerah Kabupaten Klungkung juga sangat mengharapkan Desa Wisata Paksebali menjadi desa wisata yang terus memberikan invosi-inovasi terbaru dan terus berkoordinasi dengan pemerintah terkait pengembangan desa wisata. Harapan ini juga sejalan dengan yang diinginkan oleh masyarakat yaitu pemerintah terus mendukung kegiatan kepariwisataan di Desa Wisata Paksebali.

2. Terdapat empat peran pemerintah dalam pengembangan Desa Wisata Paksebali yaitu sebagai fasilitator, perencana, evaluator dan implementer. Sebagai fasilitator pemerintah melakukan koordinasi dengan pihak desa wisata terkait pembangunan infrastruktur, adanya inovasi-inovasi baru yang diusung oleh pemerintah. Sebagai perencana pemerintah membuat master plan bersama dengan pihak desa wisata untuk meningkatkan kesadaran akan pentingnya 
perencana masa depan kepada masyarakat. Sebagai evaluator pemerintah melakukan evaluasi terhadap program-program yang sudah terlaksana seperti pembangunan infrastruktur sarana dan prasarana, partisipasi masyarakat dan koordinasi yang baik dengan pihak terkait, potensi wisata yang dikembangkan serta strategi promosi desa wisata, dan sebagai implementer pemerintah memimpin dan mengkoordinasikan program, proyek dan kegiatan untuk pengembangan desa wisata.

\section{DAFTAR PUSTAKA}

Anonim. (2018). Peran Pemerintah Daerah Dalam Pengembangan Desa Wisata Kabupaten Bandung. ihgma Retrieved from https://www.ihgma.com/peranpemerintah-daerahdalam-pengembangan-desa-wisata-kabupaten-bandung/ diakses tanggal 7 Januari 2021

Cooper, C et. al. (1993). Tourism : Principles \& Practice. London: Pitman Publishing Damanik, J. \& Weber, H.F. (2006). Perencana Ekowisata : dari Teori ke Aplikasi. Yogyakarta: Andi Publisher

Kemenparekraf/Baparekraf. (2020). Rencana Strategis Kementerian Pariwisata dan Ekonomi Kreatif/Badan Pariwisata dan Ekonomi Kreatif Tahun 2020 - 2024. Jakarta: Kemenparekraf/Baparekraf.

Pantiyasa, I. (2019). Konstruksi Model Pengembangan Desa Wisata menuju Smart Eco-Tourism di Desa Paksebali, Klungkung, Bali. Jurnal Kajian Bali Journal of Bali Studies), 9(1), 165-188. https://doi.org/10.24843/JKB.2019.v09.i01.p08

Poerwadarminta, W. J. S. (1995). Kamus Umum Bahasa Indonesia. Jakarta: PT. Balai Pustaka.

Rasyid. (2000). Makna Pemerintahan. Jakarta: PT. Mutiara Sumber Widya

Soekanto, Soerjono. (2004). Sosiologi Suata Pengantar. Jakarta : Bumi Aksara

Suwantoro, Gamal. (2004). Dasar-Dasar Pariwisata. Jakarta : Andi Publisher

Undang-Undang Nomor 10 Tahun 2009 Tentang Kepariwisataan.

Undang-Undang Nomor 23 Tahun 2015 Tentang Otonomi Daerah.

Yoeti. O.A. (2002). Perencana Strategi Pemasaran Daerah Tujuan Wisata. Jakarta: PT. Pradnya Pramita

Zakaria, F. \& Suprihardjo, D. (2014). Konsep Pengembangan Kawasan Desa Wisata di Desa Bandungan Kecamatan pakong Kabupaten Pamekasaan. Jurnal Tenik Pomits Institut Teknologi Sepuluh November Surabaya, 3(2), 245-249. http://dx.doi.org/10.12962/j23373539.v3i2.7292 